\title{
高齢期における住居選好及び公的介護サービス選好に及ぼす

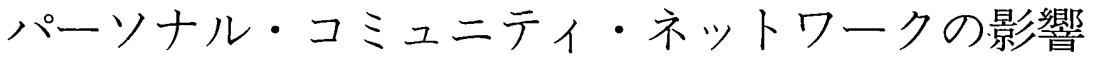 \\ RESIDENTIAL AND PUBLIC NURSING SERVICE PREFERENCES OF AGED PEOPLE EMBEDDED IN PERSONAL COMMUNITY NETWORKS
}

\author{
澤 岡 詩 野*. \\ Shino SAWAOKA
}

\begin{abstract}
The purpose of this study is to clarify the relation between personal community networks and the residential / public mursing service preferences of aged people. An investigation based on questionnaire has been conducted for aged people in Secagaya ward, Tokyo and NishiTokyo city, and Saku city. Nagàno prefecture. Three types of aged; Selective Networks Type, Restrictive Networks Type, and Individual Type were classified from the view point of their sopportive network. It was seen that Selective Networks Type aged who prefer social support from outside society rather than their kins or neighborhood, have a tendency to select housing with domiciary service. Importance of housing with domiciary for the aged will be increased in near future.
\end{abstract}

Keywords : Moving, Housing with domiciary service, Public nursing services, Selective Networks Type, Supportive network

転居、ケア付き住宅、公的介矍サービス、選択的ネットワーク型、サポーティフネットワーク

1.はじめに

\section{1-1.研究の背景}

高跉期におけるストレスフルイベント注11 の代表とされている単 身化、身体機能の低下及び転居は、高略者の社会関係を狭め、活䖝 を減少させる事が既存研究 12ににおいて碓認されている。この事 は、在宅での介助・介讙を中心とする現在の高龄者政策を正当化す る一つの論捚となっている注 2)。しかし、この前提は従来の高跲者 像やコミュニティ像を基にしたものであり、新しい洒值観やネット

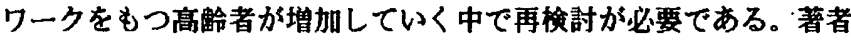
らが 1999 年に行ったアンケート調査注 3) と最近の研究 3) 4) では単 身化や転居が外出頻度に及ほす影敏が少ない高略者が相当数存在す る事を確認した。同調査では、これらの高跉者の多くは、友人との 交流や趣味目的の活野を維持する事を主要な目的として、子供との 同居ではなくケア付き住宅への転居を選択している事かかかった。

都市社会学分野では、都市化というマクロな社会の变化が個人に

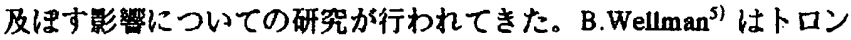
トにおける実証研癷で、都市化が進行する事によって近隣との人的 ネットワークは落れるが、ニ一ズに応したネットワークを去篹囲に 形成している事を明らかにし、これを Personal Community Networks と呼んでいる。この研究は高畄者に焦点をあてたものではなかった
が、Personal Community Networks を形成している高秢者であれば単 身化したとしてもネットワークの大半が維持されている事になり、 近隣との関保がそもそも落い為、伝居に対する影輹は少ないので、 ストレスからの回復は比較的早い事が考えられる。

外出乘度に単身化や転居の及はす影繁が少ない高跉者の存在は、 近年の日本においても Personal Community Networks を形成する高 跉者が增加した結果であると考えられる。 1-2. 研究の目的

本研究は、高柃者のパーソナルネットワークと住居選好及び公的 介愎サービス選好との閏連を分析する事を目的とする。

具体的には、Personal Community Networks を形成する高衤者 「Selective Networks 型」と、新族や地域等の拘束的ホットワーク を重視する高络者「Restrictive Networks 型」を識別し、以下 $3 つ の$ 仮説の検討を行う。撞別は、支授機能を有するパーソナルネットワ 一ク (以後、サボーティフネットワークと呼ぶ)に着目し、Selective Networks 型のサポーティフネットワークを持つ高略者を SN 型、 Restrictive Networks 型のサボーティフネットワークを持つ高昤者を RN 型とする。

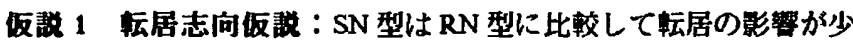
ない為に、転居志向が高い。 


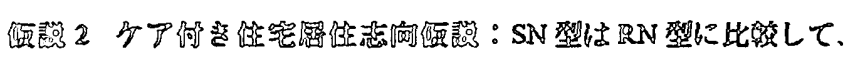

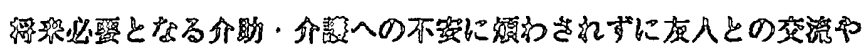

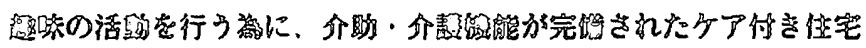
への居位志㽗方䯈い。

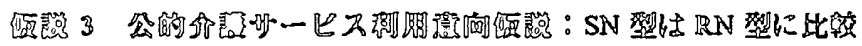

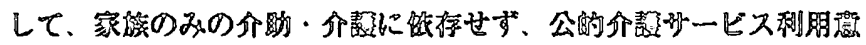
问成政い。

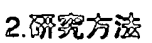

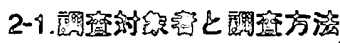

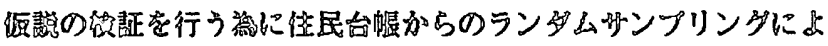

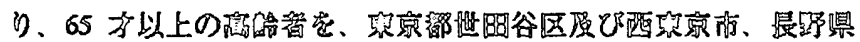

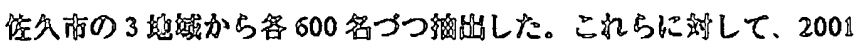

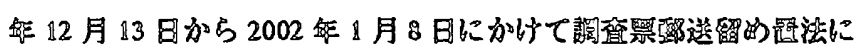

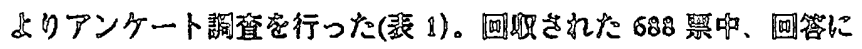

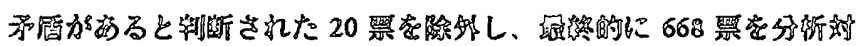
毁とした。

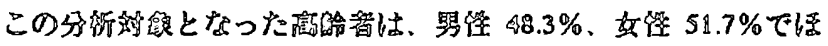

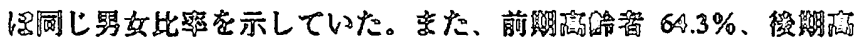

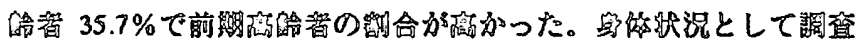

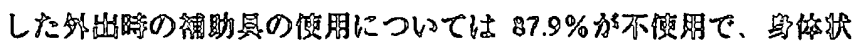

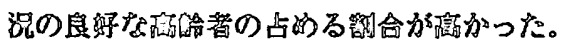

\begin{tabular}{|c|c|c|c|c|}
\hline \multirow{2}{*}{\multicolumn{5}{|c|}{ 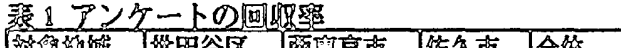 }} \\
\hline & & 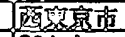 & 存公方 & 玲健 \\
\hline 9 & $219 A$ & 231 A & $238 \Delta$ & $688 \lambda$ \\
\hline & 36.5 & & & \\
\hline
\end{tabular}

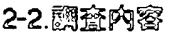

1)於ポーティプネットワーラ

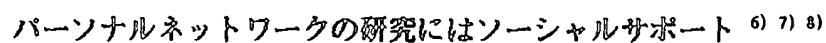

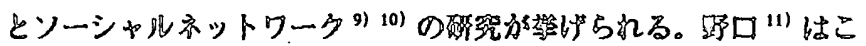

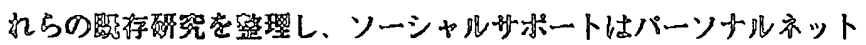

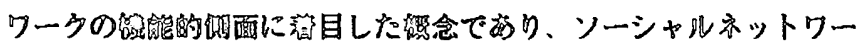

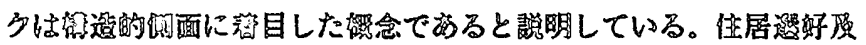

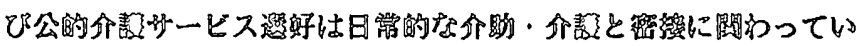

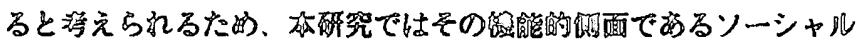

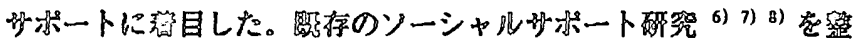

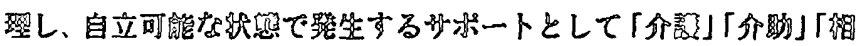

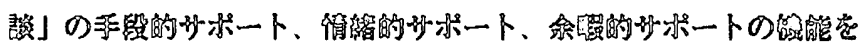

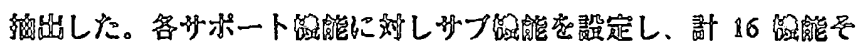

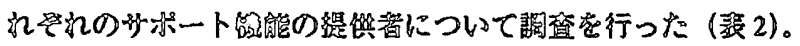

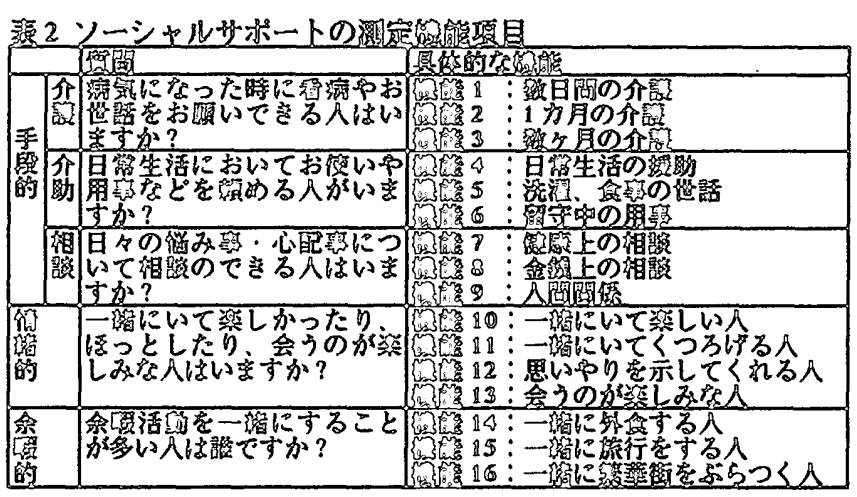

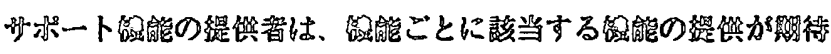

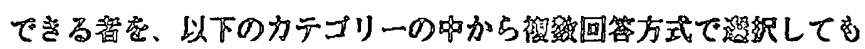

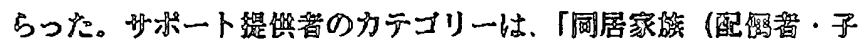

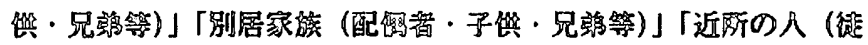

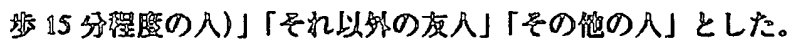

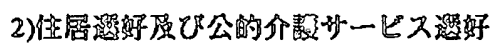

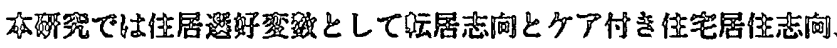

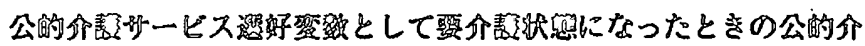

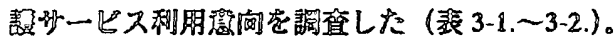

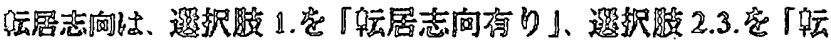

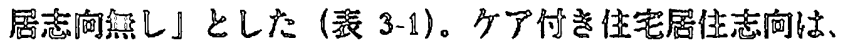

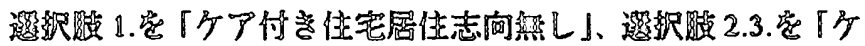

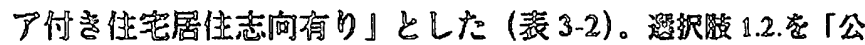

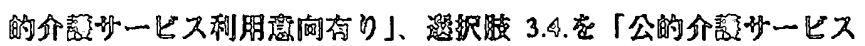

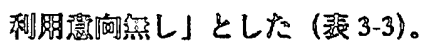

\begin{tabular}{|c|c|}
\hline 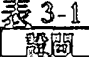 & 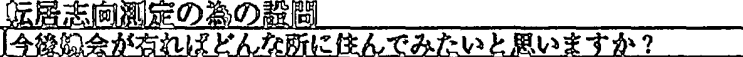 \\
\hline 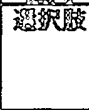 & 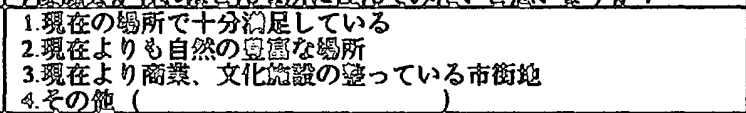 \\
\hline 邆 3-2 & 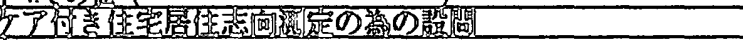 \\
\hline 琶澗 & 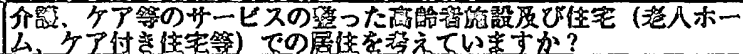 \\
\hline 趣视㘕 & 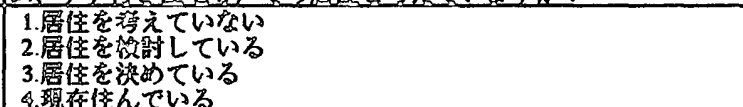 \\
\hline 3-3 & 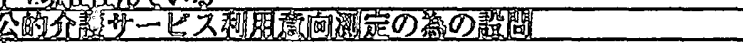 \\
\hline 設閭 & 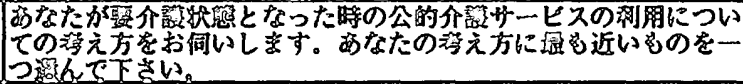 \\
\hline 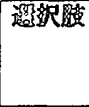 & 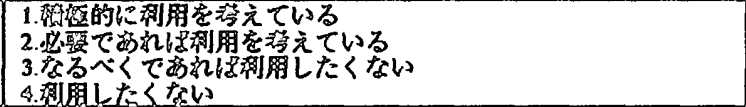 \\
\hline
\end{tabular}

3. 节か゚ーティブネットワークの祖烈化

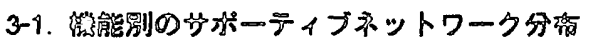

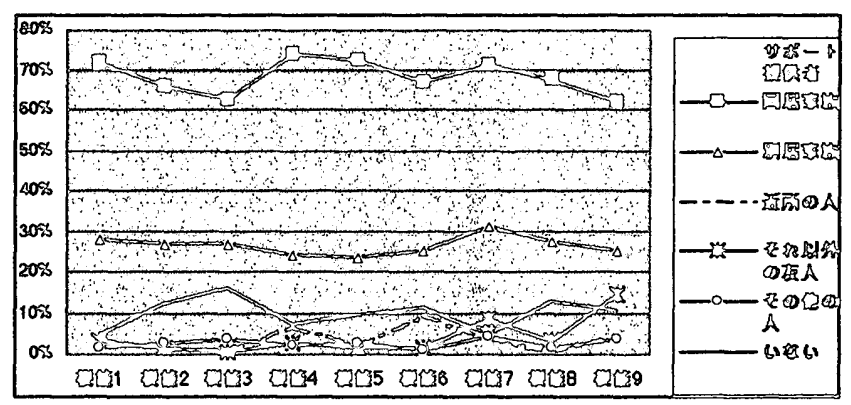

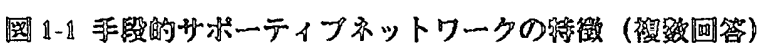

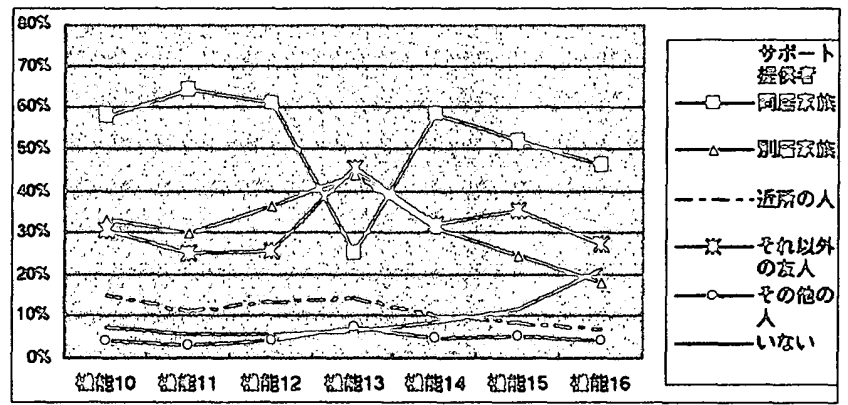

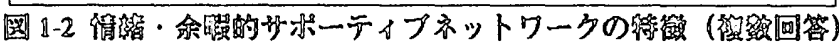


16 の機能別に機能提供者の分布をみると（表 2)、機能 13 を除い た全ての機能において同居家族が選択される㲅合が最も高かった。 近所の人がほとんど選択されていないのに対して、それ以外の友人 は手段的機能（表 2 機能 1一機能 9) ではほとんど選択されていな いが、情緒・余睱的機能（表 2 機能 10〜機能 16）では同居家族と 同様の割合を示していた。これらの倾向はいずれも既存研究 6) 7) と一致している事が確認できた。(図 1-1、図 1-2)。

3-2. サボーティブネットワークの類型化

ここでは、機能提供者の回答バタンをもとにして、以下の手顳に よりサボーティフネットワークを SN 型、RN 型に分類する。

まず、機能ごとにサポーティブネットワークを、SNf 型と RNf 型に分類した。具体的には、サボート機能 $\mathrm{f}$ の提供者として「同居 家族」「別居家族」「近所の人」以外の「それ以外の友人」「その他 の人」からもサボートの提供者を選択する場合を SNf 型とし、「同 居家族」「別居家族」「近所の人」のみに依存する場合を RNf 型と した。尚、当初想定していなかったサボート機能の提供者がいない 高跉者が、各機能において、5〜10\%程度存在していた。そこで、 この离秢者を単独 $\mathrm{f}$ 型と分類することとした。

次に機能ごとのサポーティフネットワーク類型の相互関連を見る

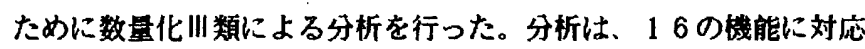
するサポーティフネットワークをアイテムとして、アイテムごとに、 前述の SNf 型、RNf 型、単独 $\mathrm{f}$ 型を 3 つのカテコリ一变数として行 った。図2はカカテコリ一変数のカテコリスコアの散布図である。

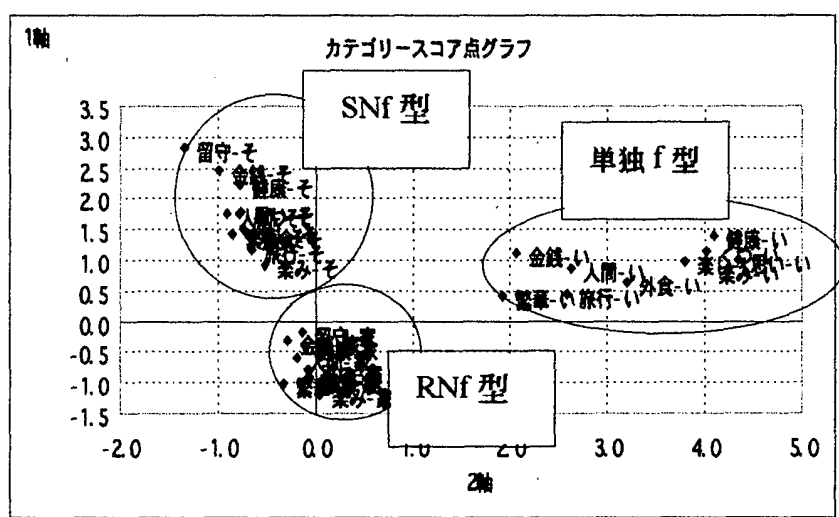

図 2 機能別サボーティフネットワーク類型

SNf 型、RNf 型、单独 $\mathrm{f}$ 型は3つの群にきれいに分かれて分布し ている。すなわち、ある機能 $\mathrm{f}$ のサボーティフネットワークが SNf

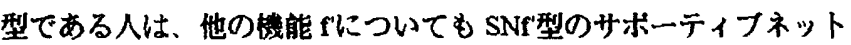
ワークを有する傾向があり、この傾向は RNf 型、単独 $\mathrm{f}$ 型にもあ る事がかかった。これらのことから、SNf 型、RNf 型、単独 $\mathrm{f}$ 型と 分類された機能別サボーティフネットワークの数をそれそれの類型 別にカウントし、SNf 型がもっとも多いときに、当該回答者のサボ 一ティフネットワークは SN 型と総合的に分類することとした。以 下同棣に、RNf 型がもっとも多いとき、单独 $\mathrm{f}$ 型がもっとも多いと き、それそれ RN 型、単独型と分類することとした。

結果、全サンブル中、 $\mathrm{SN}$ 型は $12.9 \% 、 \mathrm{RN}$ 型は $82.2 \%$ 、单独型 は 4.9\%で、RN 型の割合がもっとも多いことがわかった。
4. サポーティブネットワーク類型と転居志向、ケア付き住宅居住 志向、公的介護サービス利用意向の関連 4-1.サボーティブネットワーク類型別の転居志向者、ケア付き住宅 居住志向者、公的介護サービス利用意向者比果の比較

\begin{tabular}{|c|c|c|c|c|c|c|}
\hline & \multicolumn{2}{|c|}{ 転居 } & \multicolumn{2}{|c|}{ 尔了付光住宅 } & \multicolumn{2}{|c|}{ 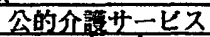 } \\
\hline & 比率 & $\chi^{2}$ 定 & 此率 & $\chi^{2}$ 㭘定 & 比率 & $x^{2}$ 莄定 \\
\hline SN 型 & $27.9 \%$ & $P=0.185$ & $28.4 \%$ & $\mathrm{P}=0.008$ & $78.8 \%$ & $P=0.140$ \\
\hline RN 型 & $25.3 \%$ & & $5153 \%$ & & $74.5 \%$ & \\
\hline
\end{tabular}

伝居志向者、ケア付き住宅居住志向者、公的介䛾サ一ビス利用意 向者の比率を、SN 型と RN 型にわけて集計を行った結果、表 4 の ようになった。これらの比率の差が統計的に有意であるかを確かめ る為に $\chi^{2}$ 模定を行った結果、ケア付き住宅居住志向は SN 型が RN 型に比較して有意に高く、ケア付き住宅居住志问仮説は支持された。 4-2.基本属性別の転居志向者、ヶア付き住宅居住志向者、公的介護 サービス利用意向者比率の比㜞

4-1.でみられたサボーティフネットワークが転居志向、ケア付き

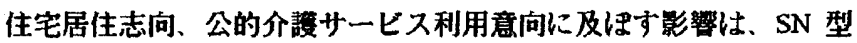
と RN 型の基本属性の㣂りによって生した見せかけものであること が教えられる。これ検討するためにサポーティフネットワークに 影響を及はしていることが考えられる基本属性をコントロールして サボーティフネットワークが転居志向、ケア付き住宅居住志向、公

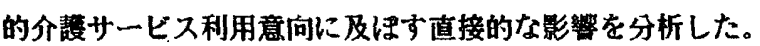

今回の調查では、年秢では前期高柃者群、身体状況注 4) として調 查した補助具の使用犾況では補助具不使用群、住居形態では非持ち 家群、家族形癿では単身世带群に SN 型が多く存在した。さらに各 地域で SN 型の占める割合は、佐久市 $6.2 \%$ 、西東京市 $12.2 \%$ 、世 田谷区 $20.7 \%$ と、地域により大きな差があった。このため本研究

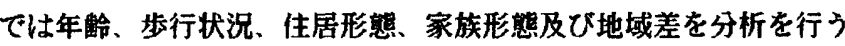
上でのコントロール裂数とした。

(1)加柃の影䇾の検討

表 5-1 年䑪別比較

\begin{tabular}{|c|c|c|c|c|c|c|}
\hline & \multicolumn{2}{|c|}{ 転居 } & \multicolumn{2}{|c|}{ ケア付き住宅 } & \multicolumn{2}{|c|}{ 公的介榙サ一ビス } \\
\hline & 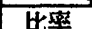 & $x^{2}$ 枪完 & 故里 & $\chi^{2}+\frac{1}{1}$ & H经 & 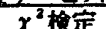 \\
\hline 前期 & $28.4 \%$ & $P=0.006$ & $19.1 \%$ & $P=0.121$ & $72.5 \%$ & $\mathrm{P}=0.534$ \\
\hline 後期 & $19: 4 \%$ & & $14.9 \%$ & & $72.5 \%$ & \\
\hline
\end{tabular}

表 5-2 年䕆によるサボーティブネットワークの影響

\begin{tabular}{|c|c|c|c|c|c|c|c|}
\hline & \multicolumn{2}{|c|}{ 転居 } & \multicolumn{2}{|c|}{ 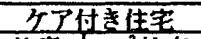 } & \multicolumn{2}{|c|}{ 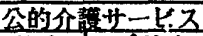 } \\
\hline & & 比率 & $x^{2}$ 梅定 & 比蓑 & $x^{2}$ 㭘定 & 比高 & $x^{2}$ 模定 \\
\hline 前 & $\frac{\text { SN 型 }}{\text { RN 型 }}$ & $\frac{30.2 \%}{28.3 \%}$ & $P=0.227$ & $\frac{288 \%}{175 \%}$ & $P=0.031$ & $\frac{80.4 \%}{74.2 \%}$ & $P=0.175$ \\
\hline 後 & SN型 & $20.0 \%$ & $P_{\text {住 }} 0.650$ & $26.7 \%$ & $P=0.115$ & $73.3 \%$ & 49 \\
\hline
\end{tabular}

転居志向者、ケア付き住宅居住志向者、公的介霞サ一ビス利用意 向者の比率を、前期高柃者群と後期高秢者群にわけて集計を行った 結果、表 5-1のようになった。これらの比率の差が梳計的に有意で あるかを確かめる為に $\chi^{2}$ 検定を行った。結果、前期群が啳期群に 比較して転居志向が有意に高かった。次に、年秢をコントロールし て、転居志向者、ケア付き住宅居住志向者、公的介愎サ一ビス利用 意向者の比率を、SN 型と RN 型にわけて集計を行った結果、表 5-2 の通りになった。これらの比率の差が繶計的に有意であるかを確か める為に $\chi^{2}$ 佮定注5)を行った。結果、前期高踰者群ではケア付き 


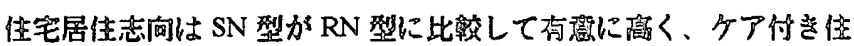

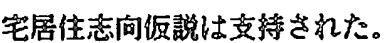

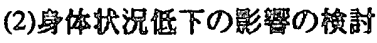

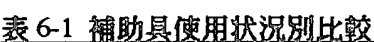

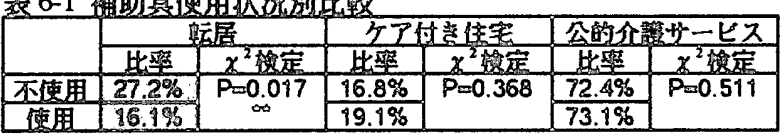

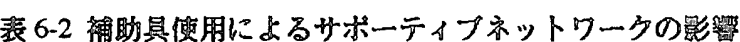

\begin{tabular}{|c|c|c|c|c|c|c|}
\hline & \multicolumn{2}{|c|}{ 枟居 } & \multicolumn{2}{|c|}{ 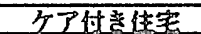 } & 公的企 & $4-6 x$ \\
\hline & 比率 & $\chi^{2}$ 榆定 & $H$ & 锤定 & 比垔 & $x^{2}$ 檢定 \\
\hline \begin{tabular}{l|l} 
不 & $\mathrm{SN}$ 型 \\
\cline { 2 - 3 } & $\mathrm{RN}$ 型
\end{tabular} & $\frac{29.7 \%}{27.0 \%}$ & $P=0.331$ & $\frac{25.6 \%}{15.3 \%}$ & $P=0.013$ & $\frac{777.8 \%}{78.3 \%}$ & $P=0.279$ \\
\hline 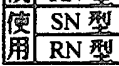 & \begin{tabular}{|l|}
$0.0 \%$ \\
$18.2 \%$ \\
\end{tabular} & $P_{m=0.466}$ & $\frac{65.7 \%}{12.2 \%}$ & $\begin{array}{l}P=0.058 \\
P=058\end{array}$ & $\frac{100.0 \%}{76.0 \%}$ & $P=0.4$ \\
\hline
\end{tabular}

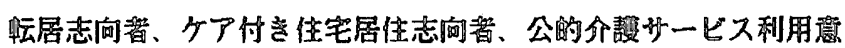

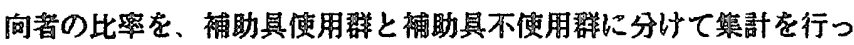

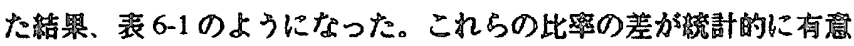

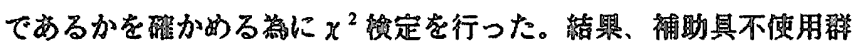

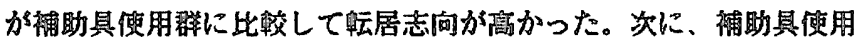

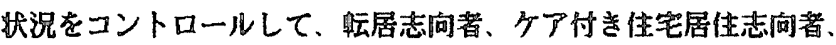

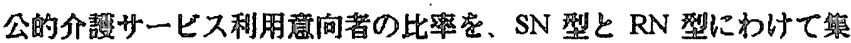

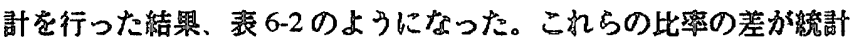

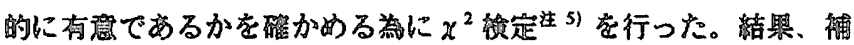

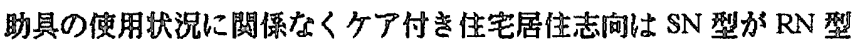

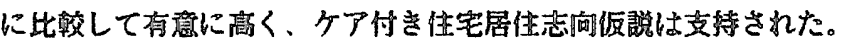

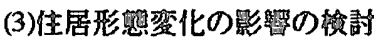

\begin{tabular}{|c|c|c|}
\hline $\begin{array}{l}\text { 邀択肢 } \\
(100)\end{array}$ & 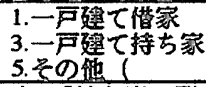 & 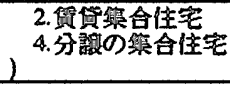 \\
\hline
\end{tabular}

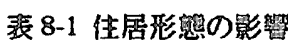

\begin{tabular}{|c|c|c|c|c|c|c|}
\hline & \multicolumn{2}{|c|}{ 媓居 } & \multicolumn{2}{|c|}{ 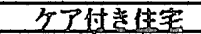 } & \multicolumn{2}{|c|}{ 公的狳筑惊一ヒス } \\
\hline & 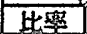 & $x^{2}$ & 地骂 & $x^{2}$ 颂定 & 的奚 & $x^{2}$ 敘定 \\
\hline \begin{tabular}{|l} 
结ち家 \\
非结ち家
\end{tabular} & $\frac{20.6 \%}{39.1 \%}$ & $P=0.000$ & $\frac{14.0 \%}{23.9 \%}$ & $P=0.001$ & $\frac{71.9 \%}{73.5 \%}$ & $P=0.350$ \\
\hline
\end{tabular}

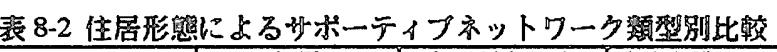

\begin{tabular}{|c|c|c|c|c|c|c|c|}
\hline & \multicolumn{2}{|c|}{ 卙居 } & \multicolumn{2}{|c|}{ 分付意住篦 } & \multicolumn{2}{|c|}{ 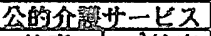 } \\
\hline & & 比甡 & $x^{2}$ & 此然 & $x^{2}$ 伤定 & 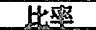 & $x^{2}$ 腚定 \\
\hline 持ち家 & 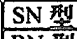 & $2 \%$ & $P=0.181$ & 31.45 & $P=0.003$ & $08.2 \%$ & $P=0.032$ \\
\hline & \begin{tabular}{|l|}
$\mathrm{SN}$ 型 \\
$\mathrm{RN}$ 刑
\end{tabular} & $\frac{41.9 \%}{35.4 \%}$ & 54 & $\frac{25.0 \%}{21.5 \%}$ & & & \\
\hline
\end{tabular}

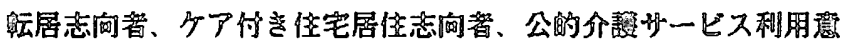

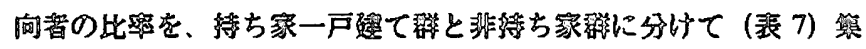

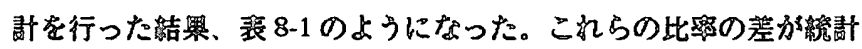

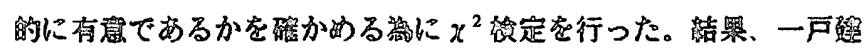

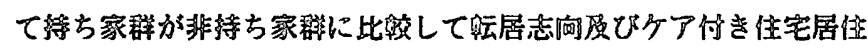

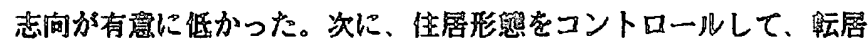

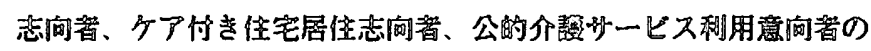

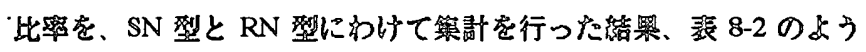

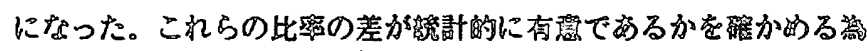

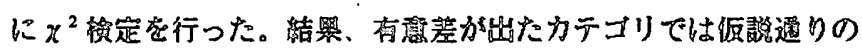

頵间が見られた。特に高觝者の多数を占める持ち家群では、SN 型 が RN 型に比較して高いケア付き住宅居住志向をむち、ケア付き住 宅居住仮説は支持された。

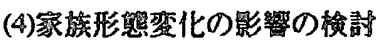

\begin{tabular}{|c|c|c|c|}
\hline 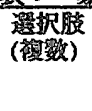 & 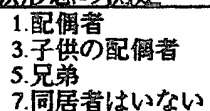 & 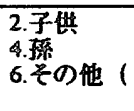 & ) \\
\hline & 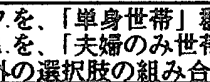 & $\begin{array}{l}\text { 群 } \\
\text { ぜを }\end{array}$ & \\
\hline
\end{tabular}

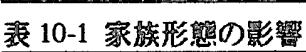

\begin{tabular}{|c|c|c|c|c|c|c|}
\hline & \multicolumn{2}{|c|}{ 檕屋 } & \multicolumn{2}{|c|}{ 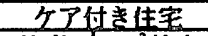 } & \multicolumn{2}{|c|}{ 公的分讙サ一Kス } \\
\hline & 比羉 & $x^{2}$ 的定 & 战高 & $x^{2}+\frac{1}{10}$ & 出卒 & $x^{2}$ 梌定 \\
\hline 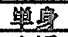 & $33.3 \%$ & $P=0.003$ & $34.7 \%$ & $P=0.000$ & $84.9 \%$ & $P=0.025$ \\
\hline 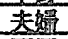 & $30.1 \%$ & & $182 \%$ & & $723 \%$ & \\
\hline 同居 & 2019 & & $12.8 \%$ & & $71.0 \%$ & \\
\hline
\end{tabular}

汪 10-2 家族形態による壮ポーティフネットワーク類型別比較

\begin{tabular}{|c|c|c|c|c|c|c|c|}
\hline & \multicolumn{2}{|c|}{ 㜔居 } & \multicolumn{2}{|c|}{ 万而付意住宅 } & \multicolumn{2}{|c|}{ 公的介到サービス } \\
\hline & & 战奥 & $x^{2}$ & 比率 & $x^{2}$ & & \\
\hline \multirow[t]{2}{*}{ 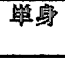 } & 烈 & $42.9 \%$ & & $33.3 \%$ & $P=0.482$ & $80.0 \%$ & \\
\hline & & & & $37.5 \%$ & & & \\
\hline \multirow[t]{2}{*}{ 夫霹 } & & 6 & \multirow{2}{*}{$P=0.160$} & $17.6 \%$ & \multirow{2}{*}{$\begin{array}{c}P=0.634 \\
\text { i } 5)^{5}\end{array}$} & 88 & \multirow{2}{*}{$P=0.061$} \\
\hline & & 32 & & $18.1 \%$ & & 70 & \\
\hline \multirow[t]{2}{*}{ 同居 } & & $24.1 \%$ & \multirow[t]{2}{*}{$P_{m=0.260}$} & $28.6 \%$ & \multirow{2}{*}{$P=0.004$} & 71. & \multirow[t]{2}{*}{$P=0.292$} \\
\hline & $\mathrm{RN}$ 㤠 & $19.2 \%$ & & $10.6 \%$ & & $76.1 \%$ & \\
\hline
\end{tabular}

枟居志间者、ケア付き住宅居住志向者、公的介篧サ一ビ久利用意

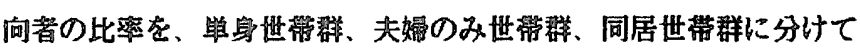

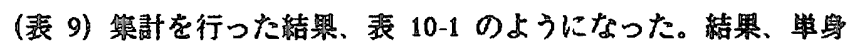

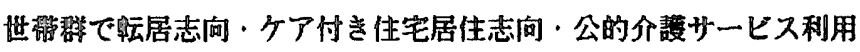

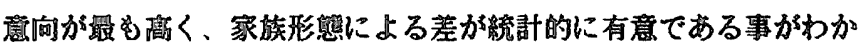
った。次に、家族形偍をコントロールして、枟居志问者、ケア付き 住宅居住柋问者、公的介霓サービス利用意间者の比率を、SN 型と RN 型にわけて舆計を行った結果、表 10-2のようになった。これら

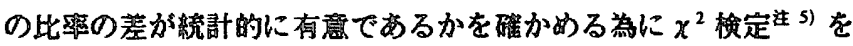
行った。結果、有意差が出たカテコリでは仮説通りの傾向が見られ た。特に漓踰者の多数を占的る同居世带群では、SN 型が RN 型に 比䡆して高いケア付き位宅居住志向をもつ傾向が見られ、ケア付き 住宅居亚悲间伍説は支措さ扎た。

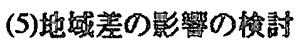

\begin{tabular}{|c|c|c|c|c|c|c|}
\hline \multicolumn{7}{|c|}{ 公的介部サービス } \\
\hline & 比陧 & $x^{2}$ 程佂 & 比率 & $x^{2}$ 湌定 & 比率 & $x^{2}$ 湌定 \\
\hline 伤公语 & $117 \%$ & $P=0.000$ & $19.4 \%$ & $P=0.240$ & $68.0 \%$ & $P=0.066$ \\
\hline 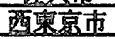 & $34.4 \%$ & & $15.0 \%$ & & $76.6 \%$ & \\
\hline 世时谷区 & $29.6 \%$ & & $18.3 \%$ & & $73.1 \%$ & \\
\hline
\end{tabular}

言 11-2 地域による将ポーティブネットワーク類型別比較

\begin{tabular}{|c|c|c|c|c|c|c|c|}
\hline & \multicolumn{2}{|c|}{ 蛙居 } & \multicolumn{2}{|c|}{ 分付秃住宅 } & \multicolumn{2}{|c|}{ 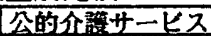 } \\
\hline & & 此率 & $x^{2}$ 檚定 & 比変 & $x^{2}$ 湌定 & 比高 & $x^{2}$ 梌定 \\
\hline 筈公市 & \begin{tabular}{|l|} 
SN 型 \\
RN 型 \\
\end{tabular} & $\frac{0.0 \%}{14.2 \%}$ & $P=0.199$ & $\frac{40.0 \%}{17.3 \%}$ & $\begin{array}{c}P=0.093 \\
\text { ait 5) }\end{array}$ & $\frac{90.9 \%}{71.6 \%}$ & $P=0.082$ \\
\hline 西東京 & $\frac{\text { SN 型 }}{\text { RN }}$ & $\frac{28.6 \%}{34.9 \%}$ & $P=0.282$ & $\frac{31.8 \%}{12.8 \%}$ & $P=0.010$ & $\frac{77.3 \%}{80.7 \%}$ & $P=0.353$ \\
\hline 世田谷 & $\begin{array}{l}\text { SN 型 } \\
\text { RN 型 }\end{array}$ & $\frac{36.1 \%}{27.7 \%}$ & $P=0.163$ & $\frac{22.9 \%}{16.4 \%}$ & $P=0.178$ & $\frac{75.8 \%}{71.0 \%}$ & $P=0.293$ \\
\hline & & & & & & & \\
\hline
\end{tabular}

舩居志向省、ケア付き住宅居住志向者、公的介讙サービス利用意

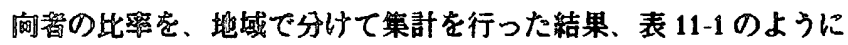


なった。これらの比率の差が統計的に有意であるかを確かめる為に $\chi^{2}$ 柤定を行った。結果、地方都市部(佐久市)に比較して東京都市 部(西東京市、世田谷区)の転居志向及び公的介護サービス利用意向 が有意に高かった。次に、地域をコントロールして、伝居志向者、 ケア付き住宅居住志向者、公的介讙サ一ビス利用意问者の比率を、 SN 型と RN 型にわけて集計を行った結果、表 11-2のようになった。 これらの比率の差が統計的に有意であるかを碓かめる為に $\chi^{2}$ 検定 注5）を行った。結果、有意差が出たカテコリでは仮説通りの傾向が 見られた。

5-3. サボーティブネットワーク類型と転居志向、ケア付き住宅居 住志向、公的介䔓サービス利用意向の直接的な関連の検討

補助具の使用状況をコントロールして3つの仮説の検討を行った 結果、サボーティフネットワークは補助具の使用状況とは独立して ケア付き住宅居住志向に影整を及ほしている事がわかった。

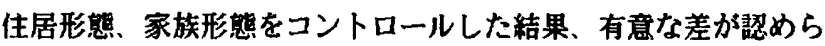
れたカテコリではケア付き住宅居住仮説は支持される事がわかった。 非持ち家群でケア付き住宅居住志向が高いにも関わらず、SN 型と RN 型に分けて比率の差の $x^{2}$ 検定を行うと有意な差が認められな いのは以下の理由による事が考えられる。非持ち家群は定住志向が 低い為、RN 型 SN 型に開係なくケア付き住宅居住志向が高い事が 考えられる。また単身世带でケア付き住宅居住志向が高いにも開わ

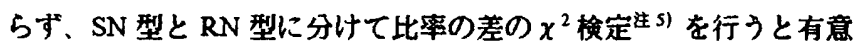
な差が珰められないのは以下の理由による事が考えられる。単身世 帯群は最も身近なサボ一トの提供主体である同居家族がいない為、 $\mathrm{SN}$ 型 RN 型に関保なくケア付き住宅居住志向が高い事が考えられ る。さらに追加調查として行ったヒアリンク調査から、夫㛿のみ世 带では可能な限り配佣者に介護・介助を期待し、配偶者に期待でき なくなった時に SN 型は公的介識サービスを利用し RN 型は子供に 依存する㖽向が見られた。夫嫖世带群 SN 型と RN 型に分けて比率 の差の $\chi^{2}$ 检定注 5) を行うと有意な差が認められないのはこの理由 による事が考えられる。住居形㷫と家族形瑟の間にこれらの交互作 用がある可能性を無視する事はできないが、本研究のケア付き住宅 居住仮説が我が国の高秢者の多数を占めている持ち家群と同居世带 群において支持されたことになる。

\section{6.結論}

6-1.哧猃

(1)ケア付き住宅居住志向仮説が、「一戸建て持ち家」群、「同居世 带」群で支持された。

(2)ケア付き住宅居住を志向する SN 型高糩者の存在は、地方都市部 (佐久市)に比較して東京都市部(西東京市、世田谷区)で多いことが 分かった。都市化により SN 型高戟者が増加して行けは、自立高 柃者を対象としたケア讨き住宅の需要は高まる事が考えられる。 6-2.今後の課題

(1)転居志向は、居住地域の商業・文化施設や交通網等の地域差の及 ほす影揰が大きい事が考えられる。これらの現状を把握した上でサ ボーティブネットークとの関連を再度分析する必要がある。 (2)加齢と共にサポーティブネットワークがどの様に後化しそれが住 居選好・公的介護サービス選好に影䇾を及はしていくのか、またそ れが加柃の効果か世代の効果かを把握する必要がある。
(3)今回のアンケート調査の追加調査として行ったヒアリンク調査で は、サボートの基本となる家族が RN 型の中で異なっている㖽向が 見られた。 RN 型の基本となる家族が誰を指しているのかについて 調查を行う必要がある。

(4)今回のアンケート調查ではケア付き住宅居を住志向する理由を分 析しておらず、今後調查分析を行う必要がある。

\section{赫辞}

調査にご協力頂きました長野県佐久市、西東京市、世田谷区の 住民の皆様並びに、研究の御指运頂いた東京工業大学 坂野達郎助 教授、共同研究者である石河䁈氏にお礼を申し上げます。

\section{注家}

注 1)米の社会生理学者 Holmes \& Rahe(1967)が、生活上のあらゆる出来事 (1 ベント) がストレス源となることに着目し、ストレスフルなライフイベント は心理生理学的な变化を引き起こす重要な要因となっている事を礁証してい る。現在「ストレスフルイベント」は、この䊈念で社会学分野、心理学分野 等のはば広い分野で使用されている。

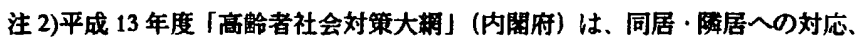
自立や介諳に通した生活㻴境整徣を、住宅と福祉政策の連势を图り推進して いくことを柱にしている。

注 3)東京近郊の立地条件の類似する軽費老人ホーム A 型とシニア住宅を 1

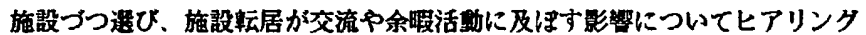
調查を行った。得られた結果を基に、両施設全居住者（軽費老人ホーム $\mathrm{A}$ 型 45 名、シニア住宅 135 名)，と比較对照群として各施設近辺の一股住宅居 住者（各 135 名）、合計 460 名を対象にアンケート調查を行った。

注 4)高昤者の身体状況測定する尺度として、ADL を用いるのが一般的であ るが、アンケート調查で ADL を測定することは困奞である。また、本研究 は自立度の高い高䍅者を対象としており、身体状況として外出時の植助具の 使用状況について調查した。

注 5)期待値が 5 以下の場合 $x^{2}$ 分布を利用する独立性の梌定は不通当である 為、Fisherの正確確率撸定により独立性の检定を行った。

\section{寮考文献}

1）川猗末美：軽費老人ホーム居住者の過応状㫛とその規定要因,社会老年学 No35,pp.47-56,1992

2）斉藤功子、西村一朗：軽費老人ホーム居住者の施設内外の交流と外出行 動に関する調查研究,日本建策学会計画采論文集 No.487,pp.87-95,1996.9

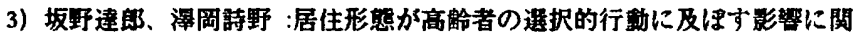
寸る研究.計画行政，第 25 卷第 2号,pp.34-44,2002

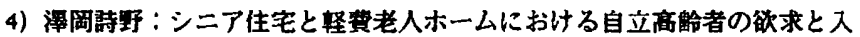
居後の通応状況に関寸る研究，日本建案学会計画系論文集 No.564,pp251255,2003.2

5) Beverly.Wellman, Barry.Wellman : Domestic Affairs And Network Relations. Journal of Social and Personal Relationships Vol.9,pp.385-409,1992

6) 古谷野亘：地域老人の社会関保にみられる僣層的補完，老年社会科学、第 19 卷第 2 号,pp. 140-149,1998

7) 野口被二：高哈者のソーシャルサボート；その概念と测定.社会老年 学,No.34,pp.37-48,1991

8）須田木綿子：大都市における男子一人暮らし老人のソーシャルネットワ 一クに関する研究.社会老年学,No.24.pp.36-51,1986

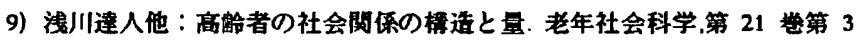
号.pp.329-336,1999

10）西下彰俊：高敷女性の社会的ネットワーク:友人ネットワークを中心に 社会老年学,No.26,pp.43-53,1987

11）野口裕二：高跉者のソーシャルネットワークとソーシャルサポート；友

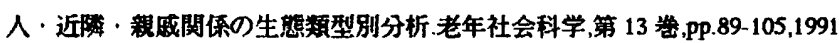

